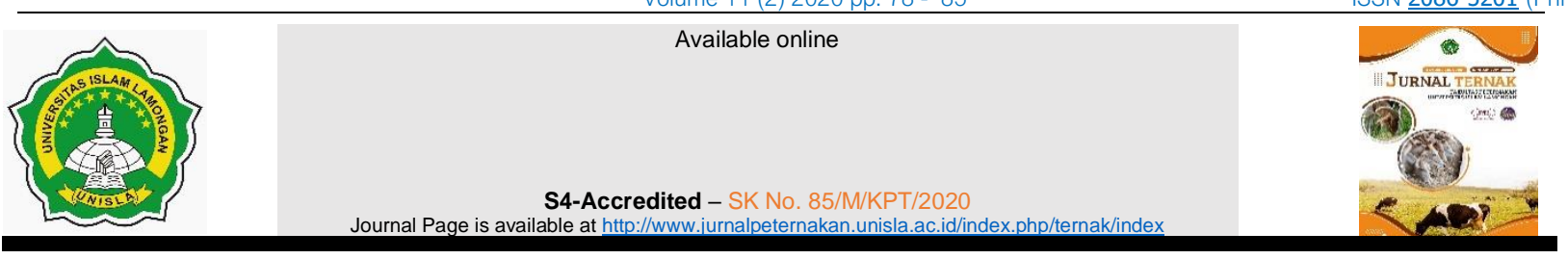

\title{
The Physical Quality of Broiler Chicken Meat Given Basal Ration Containing Avocado Seed Flour (Persea Americana Mill)
}

\author{
Adi Gunawan ${ }^{a}$, Edi Erwan $^{b *}$, Muhamad Rodiallah ${ }^{c}$ and Zumarni $^{d}$ \\ $a, b, c, d$ Animal Science Department, Faculty of Agriculture and Animal Science, State University of Sultan \\ Syarif Kasim Riau, Jl. H.R. Soebrantas No.155 KM.15 Simpang Baru Panam Pekanbaru 28293, Riau, \\ Indonesia \\ "email: erwan_edi@yahoo.com
}

\section{A R T I C L E I N F O}

Article history:

Received 17 Nopember 2020

Revised 28 Nopember 2020

Accepted 17 Desember 2020

Available online 31

Desember 2020

\section{Keywords:}

Avocado seed flour, broiler chicken, $p H$, water holding capacity and, cooking loses

\section{IEEE style in citing this} article:

A.Gunawan, E. Erwan, M.

Rodiallah and Zumarni,

"The Physical Quality of

Broiler Chicken Meat Given

Basal Ration Containing

Avocado Seed Flour (Persea

Americana Mill)

", Jurnal Ternak Universitas

Islam Lamongan, vol. 11 ,

no. 2 , pp. $78-85,2020$

\section{A B S T R A C T}

P Americana Mill contains some phytochemicals such as phenols, saponins, and flavonoids which have beneficial effect on meat quality of broiler chicken. The aim of the present study was to determine the effect of inclusion of avocado seed flour (ASF) in basal diet on meat quality of broiler chickens. A total of 80 broiler chicks of Cobb- strain were randomly assigned with following treatments: T0 (basal ration without ASF as the control), T1 (inclusion of 5\% ASF in 1 diet), T2 (inclusion of 10\% ASF in diet) and T3 (inclusion of 15\% ASF in diet) and were kept for 5 weeks. The parameters measured were meat $\mathrm{pH}$, cooking loses after slaughtering and water holding capacity. The completely randomized design was used in this experiment with 4 treatments and 5 replicates. The result showed that the inclusion of ASF significantly $(\mathrm{P}<0.01)$ decreased the meat $\mathrm{pH}$ and cooking loses after slaughtering but significantly increased $(P>0.01)$ water holding capacity. It is concluded that the best level inclusion of ASF in broiler diet in order to improve the physical quality of broiler's meat is $15 \%$.

\section{Introduction}

Nowadays, one of the commodities to meet the needs of animal origin protein for Indonesian people come from a broiler breed. Some of the advantages of broiler chicken aging are the high nutritional value with a soft meattexture, good aroma and taste, and relatively cheap price, so that it is liked by almost everyone [1]. The chemical composition of chicken meat consists of $65.95 \%$ water, $18.6 \%$ protein, $15.06 \%$ fat, and $0.79 \%$ ash. Two factors that affect the quality of meat and carcasses are before-slaughter and after-slaughter factors [3]. Some factors before the cutting that affect the quality of meat are genetic, nation, type, species, sex, livestock, age, including feed (antibiotic, and mineral) and stress. Meanwhile, some factors after slaughter that affect the quality of meat are electrical stimulation, harvesting, method of harvesting, carcass $\mathrm{pH}$, and meat, additional 
ingredients including meat crushing enzymes, intramuscular fat and storage methods [3].

Avocado seeds contain antioxidants[4] and are thought to have an effect on the physical quality of broiler chicken meat. The natural antioxidants are comprised of phenol derivatives, coumarins, sinamat hydroxy, tocopherols, diphenols, nonphenols, and ascorbic acid [5]. In addition, avocado seeds contain secondary metabolite compounds belonging to the class of alkaloids, triterpenoids, tannins, flavonoids, and saponins [6]. Antioxidants in food contribute an important role to maintain product quality, to prevent rancidity, and to change in nutritional values, discoloration and aroma, and other physical damage caused by oxidation reactions [7]. In previous research, Harahap et al. [8] concluded that the use of 5\% avocado seed flour in basalrations had no effect on weight gain, ration conversion and income over feed cost of broiler chicken. Afterwards, Nurrohman et al. [9] reported that the use of $7.5 \%$ avocado seed flour in rations did not decrease the ingest of pure metabolic energy despite lowering the ingest of coarse fat. Moreover, Nelwida [10] also reported that the replacement of corn with avocado seed flour does not affect dry ingredients, organic matter and coarse protein of broiler chicken. Nonetheless, research on the influence of avocado seed flour in rations on the quality of broiler chicken meat has never been reported. Based on the description above, the researcher conducted research by inclusion of avocado seed flour (ASF) in basal diet on meat quality of broiler chickens for the quality of meat in broiler chickens.

\section{Method}

\subsection{Material}

This study used broiler chickens aged 1 day (DOC) amounted to 80 heads without distinguishing gender (unsexing). The ration given in the study was basal ration with the utilization of ASF with different levels of administration. The tools used in the manufacture of ASF were grinder machines, analytical scales, plastics, buckets, and 20 units of battery cage sand on each cage that consisted of 4 chickens. ASF processing was done by means of kapok that was previously cleaned and washed using clean water to remove dirty attached to the surface of avocado seeds. After that, avocado seeds were sliced and boiled for 25 minutes inboiling water (temperature $100^{\circ} \mathrm{C}$ ) to decrease the tannin content in avocado seeds. After the boiling process was finished, avocado seeds were drained by winding, and then sun-dried until dry or using an oven with a temperature of $60^{\circ} \mathrm{C}$ for 10 hours. Lastly, avocado seeds were mashed using agrinder to become flour and can be given to broiler chickens, as well as cage equipment, feed, drinking places, cage lighting lamps, cage cleaning tools, scales and handsprayer. Equipment used for meat sampling are knives, analytical scales, stationery, and plastic clips (sample plastic).

\section{Method}

This study applied experimental method using a Complete Randomized Design (CRD) with 4 treatments; P0, P1, P2, and P3. Each treatment was repeated 5 times with respective test consisting of 5 heads. Treatment on this study used ASF rations.

The treatments model used in this study were as follows:

$\mathrm{P} 0=$ ration without of ASF (control)

$\mathrm{P} 1=$ ration contains $5 \%$ of $\mathrm{ASF}$

$\mathrm{P} 2=$ ration contains $10 \%$ of ASF

$\mathrm{P} 3=$ ration contains $15 \%$ of $\mathrm{ASF}$ 
Table 1. Nutritional content of research ration ingredients

\begin{tabular}{|c|c|c|c|c|c|c|}
\hline Feed Ingredients & $\begin{array}{c}\text { CrudePr } \\
\text { otein } \\
(\%)\end{array}$ & $\begin{array}{c}\text { Crude } \\
\text { Fiber } \\
(\%)\end{array}$ & $\begin{array}{c}\text { CrudeF } \\
\text { at } \\
(\%)\end{array}$ & $\begin{array}{c}\text { Energy } \\
\text { Metabolism } \\
\text { (Kcal/kg) }\end{array}$ & $\begin{array}{l}\text { Calcium } \\
(\%)\end{array}$ & $\begin{array}{c}\text { Phospor } \\
(\%)\end{array}$ \\
\hline$A^{\text {corn }}$ & 8.48 & 2.08 & 6.50 & $3,182^{c}$ & $0.22^{c}$ & $0.60^{c}$ \\
\hline Avocado Seed Flour ${ }^{\mathrm{b}}$ & 15.88 & 13.45 & 11.12 & 3,570 and & 0.65 & 0.13 \\
\hline Fish Meala & 47.70 & 1.99 & 8.00 & $3,468^{c}$ & $5.10^{c}$ & $2.80^{c}$ \\
\hline Fine Branc & 13.2 & 6.35 & 6.07 & $3,350^{f}$ & 0.19 & 0.73 \\
\hline Soybean Meala & 42.72 & 6.28 & 3.50 & $2,955 \mathrm{~g}$ & $0.87 \mathrm{~g}$ & $0.50 \mathrm{~g}$ \\
\hline Kapurd $^{\mathrm{d}}$ & - & - & - & - & 49.00 & - \\
\hline $\begin{array}{l}\text { Vitamin } \\
\text { premix }^{c}\end{array}$ & - & - & - & - & 5.38 & 1.44 \\
\hline
\end{tabular}

Source : a. Results of Laboratory Analysis of Agricultural ProductsUnri, 2018

b. Results of Laboratory Analysis of Agricultural ProductsUnri, 2019

c. Pesik et al. [11]

d. Departement of Nutrition and Feed Technology, 2013

and. Djulardi [12]

F. Results of Analysis laboratory of Feed Science and Technology Faculty of IPB

G. Fitasari et al. [13]

Table 2. The composition and nutritional content of rations used during starter periode

\begin{tabular}{lcccc}
\hline \multirow{2}{*}{ Feed Ingredients } & \multicolumn{5}{c}{ Rations } \\
\cline { 2 - 5 } & T0 (\%) & T1 (\%) & T2 (\%) & T3 (\%) \\
\hline Corn & 47.00 & 42.00 & 37.00 & 32.00 \\
Avocado Seed Flour & 0.00 & 5.00 & 10.00 & 15.00 \\
Fish Meal & 10.00 & 10.00 & 9.50 & 9.00 \\
Bran & 13.00 & 13.50 & 14.50 & 15.50 \\
Soybean Meal & 28.50 & 28.00 & 27.50 & 28.00 \\
Lime & 1.00 & 1.00 & 1.00 & 1.00 \\
Vitamin - mineral premix & 0.50 & 0.50 & 0.50 & 0.50 \\
\hline Amount & $100.00 \%$ & $100.00 \%$ & $100.00 \%$ & $100.00 \%$ \\
\hline Nutrition Ration Experiment & T0 (\%) & T1 (\%) & T2 (\%) & T3 (\%) \\
\hline Energy Metabolism (kcal/kg) & $3,120.02$ & $3,141.39$ & $3,162.61$ & $3,182.96$ \\
Crude Protein (\%) & 22.64 & 22.87 & 22.91 & 22.96 \\
Crude Fiber (\%) & 3.79 & 4.36 & 4.95 & 5.54 \\
Crude Fat (\%) & 5.64 & 5.88 & 6.11 & 6.35 \\
Ca (\%) & 1.24 & 1.26 & 1.26 & 1.25 \\
P (\%) & 0.83 & 0.80 & 0.77 & 0.74 \\
\hline
\end{tabular}

Table 3. Composition and nutrient content of rations used during finisher periode

\begin{tabular}{lcccc}
\hline \multirow{2}{*}{ Feed Ingredients } & \multicolumn{4}{c}{ Rations } \\
\cline { 2 - 5 } & T0 (\%) & T1 (\%) & T2 (\%) & T3 (\%) \\
\hline Corn & 55.00 & 50.00 & 45.00 & 40.00 \\
Avocado Seed Flour & 0.00 & 5.00 & 10.00 & 15.00 \\
Fish Meal & 10.00 & 9.50 & 9.00 & 9.00 \\
Fine Bran & 12.50 & 13.00 & 13.50 & 14.50 \\
Soybean Meal & 21.00 & 21.00 & 21.00 & 20.00 \\
Lime & 1.00 & 1.00 & 1.00 & 1.00 \\
Top Mix & 0.50 & 0.50 & 0.50 & 0.50 \\
\hline Amount & $100.00 \%$ & $100.00 \%$ & $100.00 \%$ & $100.00 \%$ \\
\hline
\end{tabular}

The Physical Quality of Broiler Chicken Meat...

Jurnal Ternak (Animal Science Journal) with CC BY NC SA license. 


\begin{tabular}{lcccc}
\hline Nutrition Ration Experiment & T0 (\%) & T1 (\%) & T2 (\%) & T3 (\%) \\
\hline Energy Metabolism (kcal/kg) & $3,136.20$ & $3,155.01$ & $3,173.82$ & $3,197.17$ \\
Crude Protein (\%) & 20.05 & 20.25 & 20.45 & 20.52 \\
Crude Fiber (\%) & 3.45 & 4.04 & 4.63 & 5.20 \\
Crude Fat (\%) & 5.86 & 6.09 & 6.31 & 6.56 \\
Ca (\%) & 1.23 & 1.23 & 1.23 & 1.25 \\
P (\%) & 0.83 & 0.79 & 0.76 & 0.74 \\
\hline
\end{tabular}

Description: Estimated content of ration material nutrition based on trial and error count referring to Table 1.

\section{Research Parameters}

The parameters observed in this study were physical quality of broiler chicken meat including $\mathrm{pH}$ value, water binding power, and milky broiler cooked chicken meat.

\section{Data Analysis}

The data were processed using analysis of variance (ANOVA) to determine the effect of treatment on the observed parameters. According to Steel and Torrie [14], if the result of ANOVA were $\mathrm{P}<0.05$, then Duncan's test would be applied.

\section{Results and Discussion}

\section{Degree of Acidity (pH) of Meat}

Average score and $\mathrm{pH}$ broiler breed chicken meat given mixed ration with avocado seed flour can be seen in Table 4 .

Table 4. Average $\mathrm{pH}$ Value of Meat (\%)

\begin{tabular}{lc}
\hline \multicolumn{1}{c}{ Treatment } & Meat $\mathrm{pH}$ \\
\hline P0 = Ration Without ASF (Control) & $6.04 \pm 0.15^{\mathrm{a}}$ \\
P1 = ration contains 5\% ASF & $5.82 \pm 0.14^{\text {from }}$ \\
P2 = ration contains 10\% ASF & $5.64 \pm 0.16^{\text {bc }}$ \\
P3 = ransum contains 15\% ASF & $5.53 \pm 0.18^{\mathrm{c}}$ \\
\hline
\end{tabular}

Description: - ASF $=$ Avocado Seed Flour

- The data displayed is Standard deviation \pm Deviation

- Different superscripts in the same column (lowercase) differ very real $(\mathrm{P}<0.01)$

The $\mathrm{pH}$ of broiler chicken meat in this study was ranged from 5.53 to 6.04 . The provision of ASF ration up to $15 \%$ had a very determinant effect $(\mathrm{P}<0.01)$ on the $\mathrm{pH}$ of broiler chicken meat. The results obtained were classified in the normal range (1). The greater the level of rationing containing avocado seed flour, the more $\mathrm{pH}$ of broiler chicken meat will decrease by almost the same $\mathrm{pH}$. This phenomenon was mutual with a study by Kartikasari et al. [1] that state, the $\mathrm{pH}$ of chicken meat ranged from 5.77-5.91. The results of this study were lower compared to the results of Prayitno et al. [15] which reported that the average $\mathrm{pH}$ value of broiler meat fed with the addition of Virgin Coconut Oil (VCO) pulp resulted in a $\mathrm{pH}$ of chicken meat ranging from 6.11 to 6.23. In addition, Soeparno [16] stated that $\mathrm{pH}$ ultimate value or normal meat is ranging from 5.4 to 5.8 .

Based on the results of this study, the increase in ASF levels in basal rations was followed by decrease in the meat $\mathrm{pH}$ value. Further tests showed that ASF administration at the level of $10 \%$ and $15 \%$ was very noticeable ini lowering $\mathrm{pH}$ versus control. Nonetheless, the treatment with the provision of ASF at the level of $5 \%$ in rations showed no difference from the control. The decrease in 
$\mathrm{pH}$ value in $\mathrm{P} 3$ treatment was suspected because at that level, the ration contained ascorbic acid or vitamin $\mathrm{C}$ which was higher than the other treatments. So that, the $\mathrm{pH}$ of the meat was also significantly decreased. The one factor that affected the tendering of the meat was the $\mathrm{pH}$ value. Meat with high $\mathrm{pH}$ (above 6.0) had a higher fat than meat with a low $\mathrm{pH}$ (about 6.0) [17]. Literature on the effect of the use of ASF in rations on poultry meat $\mathrm{pH}$ and ruminants is still very limited. Previous research have reported that the addition of $6 \%$ avocado seed flour in basal ration can improve the quality of quail meat in terms of protein and cholesterol content [4]. Some literature also reported that the influence of the use of other feed ingredients containing flavonoids in the ration was related to meat $\mathrm{pH}$. In addition, it was reported that the addition of alfafa flavonoids to the level of $15 \mathrm{mg} / \mathrm{kg}$ in basal rations had no effect on the $\mathrm{pH}$ of broiler chicken meat [17]. The consumption of broiler chicken rations can have an effect on the $\mathrm{pH}$ of meat. According to Soeparno [16], cattle that consume low and high fiber concentrates produce higher $\mathrm{pH}$ value than livestock that consume feed that contains high concentrations and low fiber.

The animals' muscle tissue during their lifespan have $\mathrm{pH}$ of about 7.2-7.4 and will decrease after cutting[7]. According to Soeparno [16], variations in postmortem muscle $\mathrm{pH}$ values are influenced by postmortem glycolysis rates, muscle glycogen reserves, ulcerable meat $\mathrm{pH}$, stress before cutting, administration of certain hormones and medications, livestock individuals, muscle kinds, electrical stimulation, and enzyme activity. Lawrie [18], added that high temperatures can also accelerate the decline of postmortem muscle $\mathrm{pH}$.

\section{Meat Water Binding Power}

The average score water binding power of broiler chicken meat fed avocado seed flour (Persea americana Mill.) is displayed in the Table 5.

Table 5. Average Value of Meat Water Binding Power

\begin{tabular}{ll}
\hline \multicolumn{1}{c}{ Treatment (\%) } & Meat Water Binding Power (\%) \\
\hline P0 = Ration Without ASF (Control) & $33.35 \pm 1.55^{\mathrm{a}}$ \\
P1 = Ransum contains 5\% ASF & $35.39 \pm 1.37^{\mathrm{b}}$ \\
P2 = Ransum contains 10\% ASF & $38.59 \pm 0.99^{\mathrm{c}}$ \\
P3 = Ration contains 15\% ASF & $40.20 \pm 1.47^{\mathrm{c}}$ \\
\hline
\end{tabular}

Description: - ASF = Avocado Seed Flour

- The data displayed is Standard deviation \pm Deviation

- Superscripting different letters in the same column (lowercase) is very real $(\mathrm{P}<0.01)$

The water binding power of broiler chicken meat in this study ranged from $33.35 \%$ to $40.20 \%$. The provision of ASF up to the level of $15 \%$ in rations had a very determinant effect $(\mathrm{P}<0.01)$ on the water binding power of broiler chicken meat. This was thought to be the cause as ASF contained a number of bioactive substances phenolic compounds that had hydroxyl groups, which were weak acidic and had one of the functions of regulating proteins [17]. Phenolic compounds will coagulate and bind to proteins in broiler meat and can inhibit the content of free water, thereby, increasing the water binding value in meat. According to Ockerman [19], the difference in the meat water binding value is influenced by the protein content. The result of this study is in line with the research of Prayitno et al. [15] The averageof water binding value of broiler chicken meat fed with the addition of Virgin Coconut Oil (VCO) pulp ranges from $30.93 \%$ to $42.21 \%$. Mega et al. [20], reported a partial turnover of commercial rations with corn and its effect on the physical quality of broiler meat resulting in water binding power of $15.70 \%$ to $34.40 \%$, lower than the results of this study.

This research showed that the value of meat water binding power increases in line with the increase in ASF levels in basal rations. Further test results showed that the average water binding 
value of broiler chicken meat ranged from $33.35 \%$ to $40.20 \%$. The increase in the meat water binding power is suspected because ASF contained flavonoids that can cause an inhibitory reaction denaturation of protein (loss of protein structure and function due to stress) [21]. The increase in the meat water binding power is in line with the increasing percentage of ASF in the ration. The protein in meat does have a role in contributing the water binding power [18]. High content of protein will be direct proportion to the ability to withstand water in meat, as to lower the free water content. The larger amount of water that comes out, the less the water binding power will be. Forrest et al. [22] states that the capacity of water binding is an important quality factor because it can affect the physical state of the meat such as tenderness, color, texture, juiceness and meatbinding.

The average value of the highest meat water binding power in the P3 treatment is $40.20 \%$, while the average value of the lowest meat water binding power in the P0 treatment is $33.35 \%$. This is allegedly due to the decrease in meat $\mathrm{pH}$ content. Consequently, the result of this study showed that the increase of chemical activity in meat was to maintain water content, and to improve the nutritional quality of broiler chicken meat. According to Soeparno [23], the meat water binding power is about $20-60 \%$. The binding capacity of the water is also affected by the $\mathrm{pH}$ of the meat [24]. Decreased $\mathrm{pH}$ values leads to decrease in meat fat levels. Purnamasari et al. [25] adds that the decrease in meat fat lead to increase in the amount of meat protein. Oktaviana [26] states that if the protein content of broiler chicken meat is getting higher, then the meat water binding power is also higher and lower fat levels simultaneously.

\section{Shrink Cook}

The average value of cooked broiler chicken meat feeded avocado seed flour ( Persea americana Mill) displayed in Table 6.

Table 6. Average Value of Shrinking Cooked Meat (\%)

\begin{tabular}{lc}
\hline \multicolumn{1}{c}{ Treatment $(\%)$} & Shrink Cook Meat \\
\hline P0 $=100 \%$ Ration Without ASF (Control) & $25.51 \pm 2.51^{\mathrm{c}}$ \\
P1 $=100 \%$ ration contains $5 \%$ ASF & $24.63 \pm 2.09^{\mathrm{bc}}$ \\
P2 $=100 \%$ ration contains $10 \%$ ASF & $22.39 \pm 1.95^{\text {from }}$ \\
P3 $=100 \%$ ration contains $15 \%$ ASF & $20.40 \pm 1.25^{\mathrm{a}}$ \\
\hline
\end{tabular}

Description: - ASF = Avocado Seed Flour

- The data displayed is Standard deviation \pm Deviation

- Superscripting different letters in the same column (lowercase) is very real $(\mathrm{P}<0.01)$

The number of cooked broiler chicken meat in this study ranged from $20.40 \%$ to $25.51 \%$. The highest average score of cooked meat is the P0 treatment with the value of $25.51 \%$. Meanwhile, the average value of the lowest meatcooker is the P3 treatment which is $20.40 \%$. The results of this study are classified in the normal range because it is approximately the same with a reported study. [15] The study had the average value of cooked broiler chicken meat fed with the addition of Virgin Coconut Oil (VCO) pulp ranges from $18.87 \%$ to $26.79 \%$. Similar average values were also reported by Hamiyanti et al. [27]. The research showed that the influence of the addition of basil flour (Ocimum basilicum) to the chemical composition and physical quality of broiler meat produces a cooking shrink by $26.41 \%$ to $27.82 \%$. The value of cooked milk on the influence of the addition of basil flour (Ocimum basilicum) which almost the same as this study is predicted as both contains flavonoids that affect the value of cooked milk. The provision of ASF up to the level of $15 \%$ in rations has a very determinant effect $(\mathrm{P}<0.01)$ on the cooked broiler chicken meat. Based on the results of this study, it can be seen that the increase in ASF levels in basal rations causes the milky value of cooked meat to decrease. This 
is predicted as the percentage of ASF ration given containing different phenolic compounds. This combination results in decreased cooked milk, in contrast with the increase in meat protein coagulation and the increase in water binding power.

This is due to the amount of chemical activity of proteins that are degreded by the process of sedation. The cooked milk is one of the important determinants of meat quality, because it is related to the small amount of water lost and the quality of nutrients that are soluble in water due to the influence of temperature and cooking. Quality meat has a low cooking shrink [28]. Cooked shrink more due to the melting of fat [18].

The greater the level of ration containing ASF, the better quality the cooked broiler chicken meat will be. The value of cooked milk in this study was influenced by the water binding power of broiler chicken meat. High water binding value produces low cooked milk, on the contrary, low water binding value will result in high cooking shrink. According to Yanti et al. [29], some factors that influence the milking of the cooked meat is the water binding power, water content. The higher the water binding power, the lower the water content in the meat. So that, the more cooked milk, the lower the meat quality. Generally, the range of cooked shrink value varies between $1.5 \%$ to $54.5 \%$ with a range of $15 \%$ to $40 \%$ [16].

\section{Conclusion}

This study concludes that the use of avocado seed flour (Persea Americana Mill) at the level of $15 \%$ in basal rations can improve the physical quality of broiler chicken meat.

\section{References}

[1] L. R. Kartikasari, B. S. Hertanto, I. Santoso, and A.M. P. Nuhriawangsa, "Physical Quality of Broiler Chicken Meat Given Corn And Soybean Based Feed With Purslane Flour Supplementation (Portulaca Oleracea),"Journal of Food Technology,Vol. 12 No. 2, 2018.

[2] W. J. Stadelman, V.M. Olson, G.A. Shmwell, S. Pasch, "Egg and Poultry Meat Processing," Ellis Haewood Ltd, 1988.

[3] A. N. Haq,D. Septinova, and P. E. Santoso, "The Physical Quality of Meat from Traditional Markets in Bandar Lampung," Integrated Livestock ScientificJournal, Vol. 3(3): 98-103, 2015.

[4] E. Tugiyanti, \& N. Iriyanti, and Y.S. Apriyant. The effect of avocado seed powder (Persea americana Mill.) on the liver and kidney functions and meat quality of culled female quail (Coturnix coturnix japonica). Veterinary World. 12. 1608-1615. 10.14202/vetworld.2019.16081615. 2019

[5] Meronda, G.Rahma, "Antioxidant and sukesteran food supplementary ingredients," Hasanuddin University, Makasar,2008.

[6] M. Marlinda, M. S. Sangi, and A. D. Wuntu, "Analysis ofsecondary metabolite compounds and toxicitytest of ethanol extract of avocado seeds (Persea americana Mill.) ," J MIPA Unsrat. 1(1) : 24-28,2012.

[7] C. H. Widjaya, "TheRole of Antioxidants AgainsttheBody," HealthyChoice, Edition IV,2008.

[8] K.M. N. Harahap,E. Erwan,R. Misrianti, "Utilization of Avocado Seed Flour (Persea americana Mill.) in Rations on Broiler Chicken Performance," Sriwijaya Livestock Journal,Vol. 8, No. 2, pp. 45-57, 2019.

[9] A. Nurrohman, V. D. Yunianto and I. Mangisah, "TheUse of Avocado Seed Flour and Its Effect onThe Ingest of Coarse Fat and Metabolic Energy of Broiler Chicken Rations," Research Report, Faculty of Animal Husbandry and Agriculture, DiponegoroUniversity, Semarang,2015. 
[10] Nelwida, "Effect of Replacement of Corn with Avocado Seeds soaked in Hot Water inRations Against Retention of Dry Ingredients, Organic Materials and Crude Proteins in Broiler Chickens," Scientific Journal of Animal Husbandry Sciences, 12(1): 50-56, 2009.

[11] H.C. Pesik, J. F. Umboh, C. A. Ratulanga, S. Pontoh, "The effect of replacing fish meal withmanggotflour (Hermetia illucens)in broiler rations against calcium and phosphorus ingest," Zootek Journal, 36. 271-279, 2016

[12] A. Djulardi, "Broiler Chicken Response to partial replacement of corn with avocado seed flour in rations," Journal of Scientific Animal Husbandry Sciences, 7. 18- 24,2004.

[13] E. Fitasari, K. Reo, N. Niswi, "Use of Different Protein Levels in Native Chickens Against The Appearance of Protein Production andDilution," Journal of Animal Husbandry Sciences.26, 73-83,2016.

[14] R. G. D. Steel, and J. H. Torrie,"Statistical Principles and Procedures, "Gramedia. Jakarta, 1993.

[15] A. H. Prayitno, E. Suryanto, and Zuprizal, "Physical andSensory Quality of Broiler Chicken Meat Fed with The Addition of Virgin Coconut Oil Pulp (VCO)," Bulletin Of AnimalHusbandry, 34(1): 55-63, 2010.

[16] Soeparno, "Meat Science andTechnology," 4th Printing, Gadjah Mada University Press, Yogyakarta,2005.

[17] K. Ouyang, M Xu, Y. Jiang,. and W Wang, Effect of alfafa flavonoids on broiler performance, meat quality, and gene expression. Canadian Journal of Animal Science 96(3) : 332341. 2016

[18] R. A. Lawrie, "MeatScience," 5th Edition, Translated by Parakkasi, A., and Y. Amwila, University of Indonesia Press, Jakarta,2003.

[19] H. W. Ockerman, "Chemistry of Meat Tissue 10th Ed," Departement of Animal Science The Ohio State University and The Ohio Agriculture Research and Development Centre, Ohio, 1983.

[20] Mega, Olfa, B.Brata, and S. Johan, " PartialReplacement of Commercial Rations oleh Corn and Its Effect on the Physical Quality ofBroiler Meat," Journal of Livestock Sciences, 19(1): 17$26,2016$.

[21] Antasionasti, I. S. Riyanto and A. Rohman,. (Antioxidant activities and phenolics contents of avocado (Persea americana Mill.) peel in vitro. Res. J. Med. Plants, 11(2): 55-56. 2017

[22] G. J. Forrest, Aberle, H. B. Hendrick, M. D. Judge, and R. A. Merkel, "Principles of Meat Science," W.H. Freeman and Company, San Francisco, 1975.

[23] Soeparno, "MeatTechnology Science," PT Gramedia Pustaka Utama, Jakarta,2009.

[24] C. Alvarado, and S. McKee, "Marination to improve functional properties and safety of poultry meat," J. Appl. Poult. Res, 16: 113-120, 2007.

[25] E. Purnamasari, Mardiana, Y. Fazila, W. H. Z. Nurwidada, and D. Febrina, "The physical and chemical properties of beef marinated inbetel nut juice (Areca catechuL.) ," National Seminar on Livestock and Veterinary Technology, 19(2): 216-226,2013.

[26] D. Oktaviana, " Theinfluence of virgin coconut oil pulp in rations on performance, carcass production, fatty, antibodies and microscopic muscles and digestive organs of broiler chickens," Thesis,Faculty of Animal Husbandry UGM, Yogyakarta,2009.

[27] A. A. Hamiyanti,B. Sutomo,A. F. Rozi,Y. Adnyono,and R. Darajat ，"The effect of the addition of basil flour (Ocimum basilicum) to the chemical composition and physical quality of broiler meat," Journal of Animal Husbandry Sciences, 23(1): 25-29, 2013.

[28] I. W. S. Dilaga, and Soeparno, "The effect of giving various levels of clenbuterol to the quality of male pork grower," Bulletin OfAnimal Husbandry, 31(4): 200-208, 2007.

[29] H. Yanti, Hidayati, and Elfawati, "Qualitybeef with pe plasticpackaging (Polyethylen)and PP plastic (Polypropylen)in the market arengka pekanbaru city,"Jurnal Peternakan, 5(1): 2-27,2008. 